\title{
Comparison of Series and Shunt FACTS Controllers for Voltage Stability in Wind Power Network
}

\author{
G. Sruthi \\ PG Student \\ VNR VJIET \\ Hyderabad
}

\author{
G. Naveen Kumar, PhD \\ Assistant Professor \\ VNR VJIET \\ Hyderabad
}

\begin{abstract}
Voltage instability has been given much attention by power system researchers and planners in recent years. One of the main reasons for voltage instability is reactive power imbalance in the power system. This paper proposes the use of wind power network for rectifying the problem of voltage instability. The aim of this paper is to identify the optimal location of FACTS controllers in an interconnected power network under $\mathrm{N}-1$ contingency. Here, to improve the Voltage Magnitude Profile and Loadability limit Thyristor Controlled Series Capacitor and Static Synchronous Compensator are used. Cat Swarm Optimization is used to determine the optimal location and size of the FACTS controllers. In this paper IEEE 14-bus system is used for testing the proposed algorithm. Simulations are performed in MATLAB using Power System Analysis Toolbox.
\end{abstract}

\section{Keywords}

CSO, N-1 contingency, STATCOM, TCSC, Voltage stability, Wind power.

\section{INTRODUCTION}

Nowadays, due to economic and environmental constraints power systems are being operated closer to their stability limits. It is very difficult to maintain a stable and secure operation of a power system. So power system stability studies have become extremely important in recent years. Power system stability [1] is the ability to return to normal or stable operating conditions after being subjected to some form of disturbance. Conversely, instability means a condition denoting loss of synchronism or falling out of step. One of the major sources of power system insecurity is voltage instability. In recent years voltage instability has been given much attention by power system researchers and planners. In power systems which are heavily loaded, faulted or which have a shortage of reactive power, maintaining voltage stability is very difficult. Although it usually has an involvement in one critical area, the problem of voltage stability concerns power system stability of whole power network [2]. Voltage stability is concerned with the stability of a power system under normal operating conditions, and after being subjected to a disturbance. Instability may occur in the form of a progressive rise or fall of voltages at some of the buses. Voltage stability can be mainly classified in two types [7]: large disturbance and small disturbance voltage stability. Large disturbance voltage stability refers to the system's ability to maintain steady voltages following large disturbances such as system faults, loss of generation, or circuit contingencies. Small disturbance voltage stability refers to the system's ability to maintain steady voltages when subjected to small perturbations such as incremental changes in system load. In this paper cat swarm optimization is used to improve large disturbance voltage stability in wind power networks.
The utilization of renewable energy sources such as Wind Energy, Fuel Cell, and Solar Energy etc. have been given much attention and interest [3] because conventional energy sources are limited and pollute the environment. Among renewable energy sources, Wind energy is the fastest growing and most promising renewable energy source as it is economically viable. Compared to other power sources, Wind energy causes minimal damage to the environment. A vast majority of the wind turbine generators installed in India are constant speed (Squirrel cage) induction generators reason being their robustness, mechanical simplicity and low price.

Using Flexible AC Transmission Systems [4, 6], one can control variables like phase angle, voltage magnitude profile etc. at chosen bus and line impedance where a voltage collapse is observed. FACTS devices are connected in multiple ways like as in series, shunt and a combination of both series and shunt. Basically static VAR compensator (SVC) and static synchronous compensator (STATCOM) are shunt connected fact devices whereas, Thyristor Controlled Series Capacitor (TCSC), Static Synchronous Series Compensator (SSSC) are series connected FACTS devices. This paper focuses on a comparison of STATCOM and TCSC devices for voltage stability improvement.

The aim of this paper is to identify the optimal location and size of STATCOM and TCSC in an interconnected power system under $\mathrm{N}-1$ contingency for voltage stability analysis. FACTS controllers are used here to improve the voltage magnitude profile and maximum loading parameter. Cat Swarm Optimization [5] is used to identify the optimal location and size of FACTS controllers.

\section{WIND POWER GENERATION}

Wind power is a renewable energy source which is widely distributed, clean, and used as an alternative to fossil fuels. It produces no greenhouse gas during operation and uses little land. Compared to other power sources, Wind energy causes minimal damage to the environment. In grid impact studies of wind power integration, the operation and security of wind farms and power grids are effected by the voltage stability. During continuous operation and system contingencies, Wind turbines absorb large amount of reactive power which in turn causes voltage instability.

\subsection{Squirrel cage induction generator}

It is directly coupled with grid. In squirrel cage induction generator the slip, and hence the rotor speed varies with the amount of power generated. Variations in rotor speed are, however, very small, approximately 1 to 2 percent. Therefore, this wind turbine type is usually referred to as a fixed speed or constant speed turbine. By changing the number of pole pairs of the stator winding, it can run at two different (but constant) speeds. A squirrel cage induction generator always consumes 
reactive power. In case of large turbines and weak grids this is undesirable. In squirrel cage induction generator, Reactive power consumption is partly or fully compensated by capacitors in order to achieve a power factor close to 1 as shown in Figure 1.

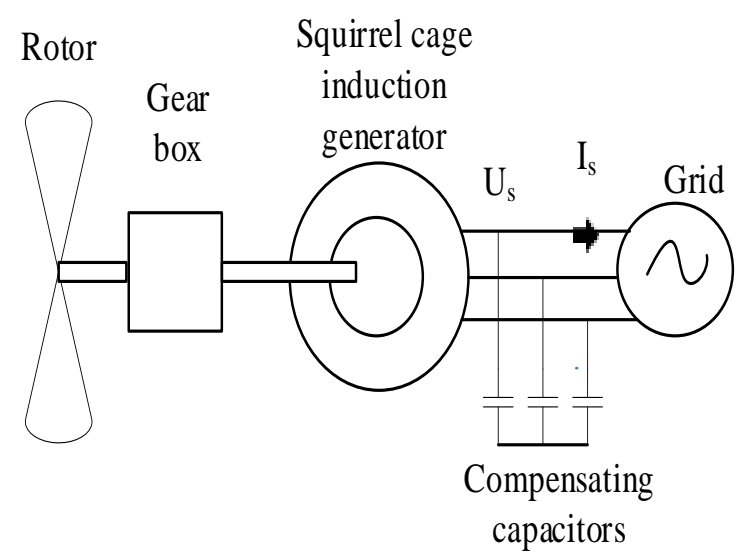

Fig. 1. Squirrel cage induction generator

\section{PROBLEM STATEMENT}

A contingency is a failure or loss of an element (e.g., generator, transformer, transmission line, etc.), or a change of state of a device (e.g., the unplanned opening of a circuit breaker in a transformer substation) in the power system. To predict the effect of outages in power systems [8], like failures of equipment, transmission line etc., Contingency analysis technique is very useful. An "outage" is nothing but the removal of equipment from service. Line contingency refers to the removal of transmission line from the system. Generator contingency refers to the removal of generator from the service, and usually the voltage variation is high. Both line contingency and generator contingency comes under large disturbances. In this paper we are doing (N-1) line outage contingency analysis FACTS devices are used to improve the voltage profile and maximum loading parameter. (N-1) contingency refers to removal of transmission lines individually for (N-1) cases. At any instant only one particular line can be removed.

\subsection{Objective function}

This objective function as defined in [9] is presented through equation (1) to (7)

$$
\mathrm{F}=\left\{\mathrm{F}_{1}, \mathrm{~F}_{2}, \mathrm{~F}_{3}\right\}
$$

The functions $F_{1}, F_{2}$ and $F_{3}$ are defined and used in the optimization process.

$$
\mathrm{F}=\mathrm{F}_{1} \emptyset_{1}+\mathrm{F}_{2} \emptyset_{2}+\mathrm{F}_{3} \emptyset_{3}
$$

The fitness function is defined as a sum of three terms with individual criteria. The first part of the objective function concerns the voltages level. It is favorable that buses voltages be as close as possible to 1 P.U. Equation (3) shows the voltage deviation in all buses.

$$
\mathrm{F}_{1}=\mathrm{F}_{\mathrm{V}}=\left[\sum_{\mathrm{i}=1}^{\mathrm{n}_{\mathrm{b}}}\left(\mathrm{V}_{\mathrm{i}}-1\right)^{2}\right]^{1 / 2}
$$

Where $n_{b}$ is the number of buses and $\mathrm{V}_{\mathrm{i}}$ is the voltage of bus $i$.

$\mathrm{F}_{2}$-this function represents the optimal location and size of STATCOM and TCSC which has its dependence on $\mathrm{F}_{1}$. This is related to having the minimum possible STATCOM, TCSC sizes regarding to the control of STATCOM, TCSC and is given by eq (4);

$$
\mathrm{F}_{2}=\mathrm{F}_{S}=\alpha \sum_{j=1}^{m} Q_{j}
$$

Where ' $\mathrm{m}$ ' is the number of STATCOM's, TCSC's and ' $Q_{j}$ ' is the value of STATCOM's, TCSC's kvar and ' $\alpha$ ' is a weight in order that the terms in the fitness function are comparable in magnitude, Value of STATCOM's, TCSC's kvar considering the control strategy and STATCOM's, TCSC's model is achieved.

The maximum loadability of power system is extremely important and hence it is considered as the third part of the objective function. The third issue in our problem is determining inverse of maximum loadability, given as follows

$\mathrm{F}_{3}=\mathrm{F}_{\mathrm{SM}}=1 / \lambda_{\text {Critical }}$

Therefore, the objective function is given by the following equation.

$F=\emptyset_{1} F_{V}+\emptyset_{2} F_{S}+\emptyset_{3} F_{S M}$

The parameter that is used to examine system proximity to voltage collapse is called Maximum Voltage Parameter, $\lambda$. In the bifurcation theory, it is assumed that system equations depend on a set of parameters together with state variables as shown in the equation below:

$\Psi(\rho, \lambda)=0$

Here, " $\rho$ " is power system state variable and " $\lambda$ " represents loading parameter. Stability or instability properties are assessed varying "slowly" these parameters. The reason behind improving the maximum loading parameter is to understand the maximum loadability limits of the interconnected power network and to determine the stability limits for run-up under secure conditions.

\section{METHODS AND DEVICES 4.1 Introduction to Cat Swarm Optimization}

Many fields can take advantage of optimization techniques. With continuous improvement in artificial intelligence techniques, the use of these techniques in power systems is playing an important role to know the optimal location of FACTS devices. These algorithms imitate the creature's swarm behavior and model into algorithm, such as Ant Colony Optimization (ACO) which imitates the behavior of ants, Particle Swarm Optimization (PSO) which imitates the behavior of birds, Bee Colony Optimization (BCO) which imitates the behavior of bees, and Cat Swarm Optimization (CSO) which imitates the behavior of cats. In these optimization techniques, CSO [10] is one of the best algorithms to find the global solution.

In CSO referred from [11], every cat has its own position composed of D dimensions, velocities for each dimension, fitness value, and a flag. Fitness value represents the accommodation of the cat to the fitness function and flag is used to identify whether the cat is in seeking mode or tracing mode. The final solution would be the best position of one of the cats. Till the end of the iterations CSO preserves the optimal solution. The CSO algorithm was modeled on the common behavior of cats. The algorithm for CSO is shown in Figure 2. Based on the behavior of cats this algorithm can be divided into two models namely seeking mode and tracing mode. 


\subsubsection{Seeking mode}

The seeking mode of CSO is used for modeling the behavior of cats in resting time and being-alert for observing its environment for its next move. The seeking mode can be described in 5 steps as follows:

Step 1: Select the total number cats that have to be considered.

Step 2: For each cat, a fixed range of velocities has to be assumed

Step 3: Calculate the fitness values $\left(\mathrm{F}_{\mathrm{S}}\right)$ of all candidate points.

Step 4: Select how many cats to be available in seeking mode.

Step 5: Randomly pick the cat from the total number of cats and apply in seeking mode according to the eq (8)

$$
\mathrm{P}_{\mathrm{kn}}=\left[(1 \pm 0.3) \mathrm{R}_{\text {and }}()\right] * \mathrm{P}_{\mathrm{K}}
$$

Where, $\mathrm{n}=1,2,3,4,5$, etc. Where Rand ( ) is a random value in the range of $[0,1]$.

Here, ' $\mathrm{P}$ ' is the pick-up of the cat from a random number of cats and $\mathrm{P}_{\mathrm{k}}$ is the total number of cats available for application.

$$
\mathrm{P}_{\mathrm{i}}=\left(\mathrm{F}_{\mathrm{si}}-\mathrm{F}_{\mathrm{sb}}\right) /\left(\mathrm{F}_{\text {Smax }}-\mathrm{F}_{\text {Smin }}\right) ; 0<\mathrm{i}<\mathrm{j}
$$

If the goal of the fitness function is to find the minimum solution,

$$
\mathrm{F}_{\mathrm{sb}}=\mathrm{F}_{\text {Smax }} ; \text { Otherwise } \mathrm{F}_{\mathrm{sb}}=\mathrm{F}_{\text {Smin }}
$$

\subsubsection{Tracing mode}

Tracing mode is the sub-model for modeling the cat in tracing some targets. The tracing mode can be described in 3 steps as follows:

Step 1: Update the velocities for every dimension $\left(\mathrm{V}_{\mathrm{k}, \mathrm{d}}\right)$ according to eq (11).

Step 2: Check if the velocities are in the range of maximum velocity. In case the new velocity is over range, set it be equal to the limit.

Step 3: Update the position of cat $_{\mathrm{k}}$ and again calculate the best fitness value. Proceed till the best fitness value is obtained and correspondingly, the cat location and the velocity.

$$
\mathrm{V}_{\mathrm{k}, \mathrm{d}}=\mathrm{V}_{\mathrm{k}, \mathrm{d}}+\mathrm{r}_{1} * \mathrm{c}_{1} *\left(\mathrm{P}_{\text {best }, \mathrm{d}}-\mathrm{P}_{\mathrm{k}, \mathrm{d}}\right), \mathrm{d}=1,2 \ldots \mathrm{M}
$$

Where $P_{\text {best }, d}$ is the position of the cat, which has the best fitness value. $V_{k, d}$ the velocity for every dimension. $\mathrm{P}_{\mathrm{k}, \mathrm{d}}$ the position of $\mathrm{cat}_{\mathrm{k}}, \mathrm{c}_{1}$ is a constant and $\mathrm{r}_{1}$ is a random value in the range of $[0,1]$.

$\mathrm{P}_{\mathrm{k}, \mathrm{d}}$ can be expressed as the eq (12)

$$
\mathrm{P}_{\mathrm{k}, \mathrm{d}}=\mathrm{P}_{\mathrm{k}, \mathrm{d}}+\mathrm{V}_{\mathrm{k}, \mathrm{d}}
$$

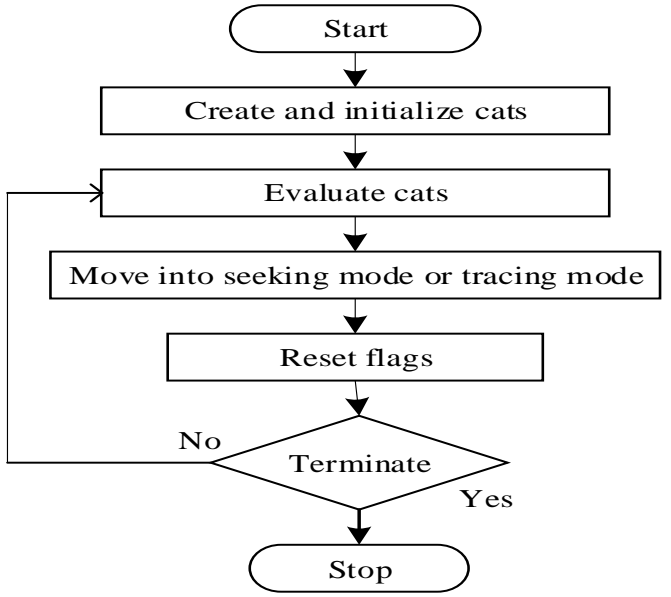

Fig 2. Algorithm for Cat Swarm Optimization

\subsection{Thyristor Controlled Series Capacitor (TCSC)}

TCSC shown in Figure 3 is series type compensator, used to reduce the possibility of voltage collapse. TCSC is used to improve power flow capability of the line as well as to enhance system stability. To reduce the series reactive impedance and to minimize receiving end voltage variation series capacitive compensation is used [12].

The steady -state impedance of the TCSC is that of a parallel LC circuit, consisting of fixed capacitive impedance, $\mathrm{X}_{\mathrm{C}}$ and a variable inductive impedance of the TCSC by delay is shown in eq (13)

$$
\begin{gathered}
X_{\operatorname{TCSC}}(\alpha)=\frac{\mathrm{X}_{\mathrm{C}} \mathrm{X}_{\mathrm{L}}(\alpha)}{\mathrm{X}_{\mathrm{L}}(\alpha)-\mathrm{X}_{\mathrm{C}}} \\
\text { Where, } \mathrm{X}_{\mathrm{L}}(\alpha)=\mathrm{X}_{\mathrm{L}} \frac{\pi}{\pi-2 \alpha-\sin 2 \alpha}, \mathrm{X}_{\mathrm{L}} \leq \mathrm{X}_{\mathrm{L}}(\alpha) \leq \infty
\end{gathered}
$$

$\mathrm{X}_{\mathrm{L}}=\omega \mathrm{L}$, and $\alpha$ is the delay angle measured from the crest of the capacitor voltage (or, equivalently, the zero crossing of the line current). The impedance of the TCSC by delay is shown in eq (14).

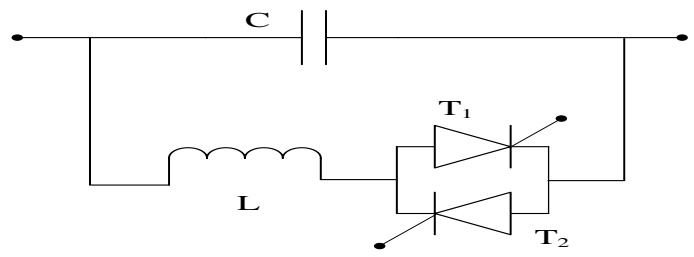

Fig: 3 Simple diagram of TCSC device

\subsection{Static Synchronous Compensator (STATCOM)}

STATCOM is used to supply adjustable amount of reactive power to the ac power system to which they are connected [13]. STATCOM is a fast acting device. Performance of wind power network can be improved using FACTS devices such as STATCOM [14]. STATCOM is used to improve the voltage profile and maximum loading parameter.

The controller of a STATCOM operates the converter in a particular way that the phase angle between the converter voltage and the transmission line voltage is dynamically adjusted and synchronized so that the STATCOM generates or absorbs desired VAR at the point of coupling connection shown in Figure 4. If the amplitude of output voltage $U$ is 
increased above that of the $\mathrm{AC}$ system voltage $\mathrm{U}_{\mathrm{T}}$, a leading current is produced, i.e. the STATCOM is seen as a conductor by the AC system and reactive power is generated. Decreasing the amplitude of the output voltage below that of the AC system then reactive power is absorbed which is shown in eq (15).

$\mathrm{I}_{\mathrm{q}}=\frac{\mathrm{U}_{\mathrm{T}-} U_{e q}}{\mathrm{X}_{\mathrm{eq}}}$

Where $\mathrm{I}_{\mathrm{q}}$ is the reactive current injected by the STATCOM. $\mathrm{U}_{\mathrm{T}}$ is the STATCOM terminal voltage. $\mathrm{U}_{\mathrm{eq}}$ is the equivalent Thevenin voltage seen by the STATCOM. $X_{\text {eq }}$ is the equivalent Thevenin reactance of the power system seen by the STATCOM.

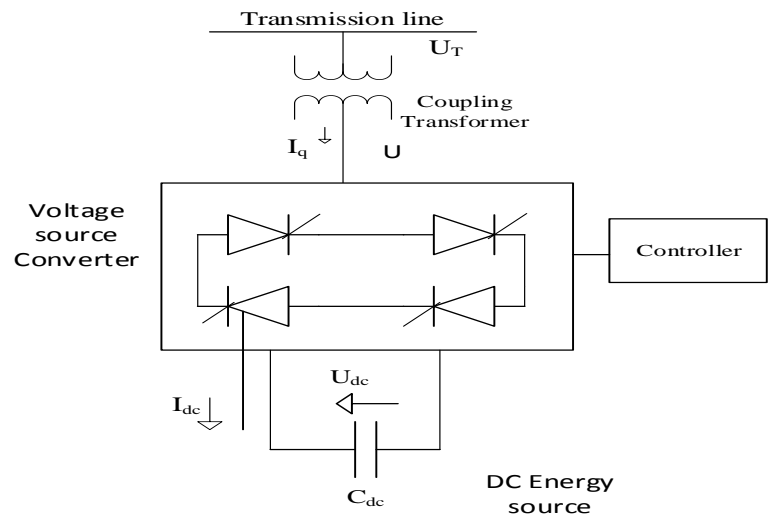

Fig 4. Reactive power generations by a STATCOM

\section{IMPLEMENTATION PROCEDURE}

The specifications of IEEE 14 bus system can be given as: the number of buses being 14, the number of lines being 16 , the wind turbine generator count is 4 and the number of loads being 11. Base MVA of 100 is assumed for the test case. All the analysis and testing here is performed in MATLAB/Simulink using power system analysis toolbox. Figure 5 shows the IEEE 14 bus network on which all the experimentation has been performed.

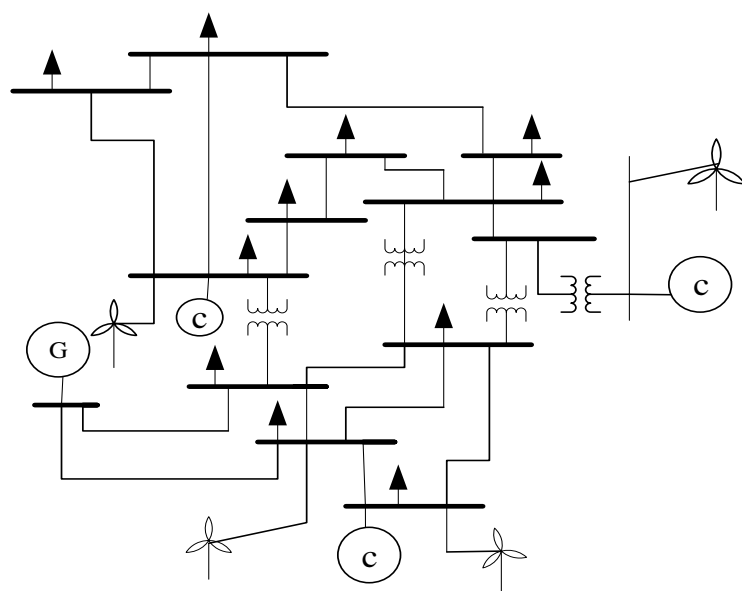

Fig.5. Standard IEEE 14-bus system with squirrel cage induction generator

First we run the Continuous Power Flow for the predisturbance case and the voltage magnitudes at various buses are noted. And now we introduce the line outage and rerun the $\mathrm{CPF}$ routine to know the deterioration of voltages. Similarly we continue this for $\mathrm{N}-1$ cases and the maximum loading parameter and the voltages at the respective buses is noted. From the N-1 contingency analysis we identify the critical cases for which there is maximum deviation in the voltages. On analysis we found that Line-4, Line- 8 and Line-9 outages shows a higher rate of deterioration of voltages. After identifying the worst locations for line contingencies, the TCSC's and STATCOM's are introduced into the system at appropriate places applying CSO technique, which is used to decide both location and VAR requirements for the FACTS device. The maximum loadability limit and voltage magnitude profile of the system at the weakest buses have been brought back to the pre disturbance values.

\section{RESULTS AND DISCUSSION}

Table 7 shows the results for N-1 contingency analysis. For each line outage, only the worst cases of voltage magnitude profiles at particular buses in P.U. are shown. The remaining blocks represent voltage magnitude profiles in Acceptable Limit (AL). We found that Line-4, Line- 8 and Line-9 outages have reported very low voltage profiles and the solution using CSO has been applied to these three cases. In these three cases Line-8 outage shows higher deterioration of voltages. In this paper Line-8 outage explained in detail.

\section{Case study 1}

\section{FACTS used: TCSC (Line 8 outage)}

Among three TCSC's, two TCSC's are in seeking mode and one is in tracing mode and their size in terms of VAR requirements is sorted based on number of iterations run with various number of VAR ratings induced in them using Cat Swarm Optimization. The optimal location of TCSC's is decided by using N-1 contingency analysis given in Table7. For this technique 50 Numbers of iteration are run, of which the global best solution is taken into consideration. The best location for three TCSC's for line 8 contingency is between buses 9-7, 10-11 and 11-6 respectively. The size of TCSC's is equal to $0.01 \mathrm{kvar}, 8.8 \mathrm{kvar}$ and $0.01 \mathrm{kvar}$ respectively. The size of TCSC's is proven using Tables 1 to 3 .

Table 1: TCSC 3 between buses 11 and 6 applied in tracing mode

\begin{tabular}{|c|c|c|c|}
\hline $\begin{array}{c}\text { TCSC } 1 \\
\text { between } \\
\text { buses } 9 \text { and } 7 \\
\text { in kvar }\end{array}$ & $\begin{array}{c}\text { TCSC } 2 \\
\text { between buses } \\
10 \text { and } 11 \text { in } \\
\text { kvar }\end{array}$ & $\begin{array}{c}\text { TCSC } 3 \text { (Tracing } \\
\text { mode) between } \\
\text { buses } 11 \text { and } 6 \text { in } \\
\text { kvar }\end{array}$ & $\overline{\lambda_{\max }}$ \\
\hline 1 & 1 & 0.01 & 2.9886 \\
\hline 1 & 1 & 0.5 & 2.9886 \\
\hline 1 & 1 & 1 & 2.9886 \\
\hline 1 & 1 & 2 & 2.9886 \\
\hline 1 & 1 & 3 & 2.9886 \\
\hline 1 & 1 & 5 & 2.9886 \\
\hline 1 & 1 & 6 & 2.9886 \\
\hline 1 & 1 & 8 & 2.9886 \\
\hline 1 & 1 & 9 & 2.9886 \\
\hline 1 & 1 & 10 & 2.9886 \\
\hline 1 & 1 & 11 & 2.9886 \\
\hline 1 & 1 & 12 & 2.9886 \\
\hline 1 & 1 & 13 & 2.9886 \\
\hline 1 & 1 & 14 & 2.9886 \\
\hline 1 & 1 & 15 & 2.9886 \\
\hline 1 & 1 & 16 & 2.9886 \\
\hline 1 & 1 & 17 & 2.9886 \\
\hline 1 & 1 & 18 & 2.9886 \\
\hline 1 & 1 & 19 & 2.9886 \\
\hline 1 & 1 & 20 & 2.9886 \\
\hline
\end{tabular}


Table 2: TCSC 2 between buses 10 and 11 applied in tracing mode

\begin{tabular}{|c|c|c|c|}
\hline $\begin{array}{c}\text { TCSC 1 } \\
\text { between } \\
\text { buses } 9 \text { and } \\
7 \text { in kvar }\end{array}$ & $\begin{array}{c}\text { TCSC 2 (Tracing } \\
\text { mode) between } \\
\text { buses 10 and 11 in } \\
\text { kvar }\end{array}$ & $\begin{array}{c}\text { TCSC 3 } \\
\text { between buses } \\
11 \text { and 6 in } \\
\text { kvar }\end{array}$ & $\lambda_{\max }$ \\
\hline 1 & 0.01 & 0.01 & 2.9886 \\
\hline 1 & 0.5 & 0.01 & 2.9886 \\
\hline 1 & 1 & 0.01 & 2.9886 \\
\hline 1 & 1.5 & 0.01 & 2.9886 \\
\hline 1 & 2 & 0.01 & 2.9886 \\
\hline 1 & 4 & 0.01 & 2.9886 \\
\hline 1 & 6 & 0.01 & 2.9886 \\
\hline 1 & 8 & 0.01 & 2.9886 \\
\hline 1 & 8.5 & 0.01 & 2.9886 \\
\hline 1 & 8.8 & 0.01 & 2.989 \\
\hline 1 & 8.9 & 0.01 & 2.9886 \\
\hline 1 & 9 & 0.01 & 2.9889 \\
\hline 1 & 10 & 0.01 & 2.9889 \\
\hline 1 & 11 & 0.01 & 2.9889 \\
\hline 1 & 12 & 0.01 & 2.9887 \\
\hline 1 & 13 & 0.01 & 2.9887 \\
\hline 1 & 14 & 0.01 & 2.9887 \\
\hline 1 & 16 & 0.01 & 2.9886 \\
\hline 1 & 18 & 0.01 & 2.9886 \\
\hline 1 & 20 & 0.01 & 2.9886 \\
\hline & & & \\
\hline
\end{tabular}

Table 3: TCSC 1 between buses 9 and 7 applied in tracing mode

\begin{tabular}{|c|c|c|c|}
\hline $\begin{array}{c}\text { TCSC 1 (Tracing } \\
\text { mode) between } \\
\text { buses 9 and 7 in } \\
\text { kvar }\end{array}$ & $\begin{array}{c}\text { TCSC 2 } \\
\text { between } \\
\text { buses 10 and } \\
11 \text { in kvar }\end{array}$ & $\begin{array}{c}\text { TCSC 3 } \\
\text { between buses } \\
11 \text { and 6 in } \\
\text { kvar }\end{array}$ & $\lambda_{\max }$ \\
\hline 0.01 & 8.8 & 0.01 & 2.989 \\
\hline 0.5 & 8.8 & 0.01 & 2.989 \\
\hline 1 & 8.8 & 0.01 & 2.989 \\
\hline 1.5 & 8.8 & 0.01 & 2.989 \\
\hline 2 & 8.8 & 0.01 & 2.989 \\
\hline 3 & 8.8 & 0.01 & 2.988 \\
\hline 5 & 8.8 & 0.01 & 2.989 \\
\hline 6 & 8.8 & 0.01 & 2.989 \\
\hline 7 & 8.8 & 0.01 & 2.9523 \\
\hline 7.5 & 8.8 & 0.01 & 2.9548 \\
\hline 8 & 8.8 & 0.01 & 2.9566 \\
\hline 9 & 8.8 & 0.01 & 2.9605 \\
\hline 9.5 & 8.8 & 0.01 & 2.9599 \\
\hline 10 & 8.8 & 0.01 & 2.9605 \\
\hline 11 & 8.8 & 0.01 & 2.9646 \\
\hline 12 & 8.8 & 0.01 & 2.989 \\
\hline 14 & 8.8 & 0.01 & 2.989 \\
\hline 16 & 8.8 & 0.01 & 2.989 \\
\hline 18 & 8.8 & 0.01 & 2.989 \\
\hline 20 & 8.8 & 0.01 & 2.989 \\
\hline & & & \\
\hline & & &
\end{tabular}

FACTS used: STATCOM (Line 8 outage)

The optimal location of STATCOM's is decided by using N-1 contingency analysis given in Table7. The best location of three STATCOM's for line 8 outage is at buses 9, 10 1nd 11 respectively. The size of STATCOM's is equal to $12.7 \mathrm{kvar}$, $0.01 \mathrm{kvar}$ and $0.01 \mathrm{kvar}$ respectively. The size of STATCOM's is proven using Tables 4 to 6 .

Table 4: STATCOM 3 at bus 11 applied in tracing mode

\begin{tabular}{|c|c|c|c|}
\hline $\begin{array}{c}\text { STATCOM 1 } \\
\text { at bus9 in kvar }\end{array}$ & $\begin{array}{c}\text { STATCOM 2 at } \\
\text { bus 10 in kvar }\end{array}$ & $\begin{array}{c}\text { STATCOM } \\
\text { 3(Tracing mode) } \\
\text { at bus 11 in kvar }\end{array}$ & $\lambda_{\max }$ \\
\hline 1 & 1 & 0.01 & 2.5913 \\
\hline 1 & 1 & 0.5 & 2.5913 \\
\hline
\end{tabular}

\begin{tabular}{|l|l|l|l|}
\hline 1 & 1 & 1 & 2.5913 \\
\hline 1 & 1 & 1.5 & 2.5913 \\
\hline 1 & 1 & 2 & 2.5913 \\
\hline 1 & 1 & 3 & 2.5913 \\
\hline 1 & 1 & 4 & 2.5913 \\
\hline 1 & 1 & 5 & 2.5913 \\
\hline 1 & 1 & 6 & 2.5913 \\
\hline 1 & 1 & 7 & 2.5913 \\
\hline 1 & 1 & 8 & 2.5913 \\
\hline 1 & 1 & 9 & 2.5913 \\
\hline 1 & 1 & 10 & 2.5913 \\
\hline 1 & 1 & 12 & 2.5913 \\
\hline 1 & 1 & 13 & 2.5913 \\
\hline 1 & 1 & 14 & 2.5913 \\
\hline 1 & 1 & 15 & 2.5913 \\
\hline 1 & 1 & 17 & 2.5913 \\
\hline 1 & 1 & 19 & 2.5913 \\
\hline 1 & 1 & 20 & 2.5913 \\
\hline
\end{tabular}

Table 5: STATCOM 2 at bus 10 applied in tracing mode

\begin{tabular}{|c|c|c|c|}
\hline $\begin{array}{c}\text { STATCOM } \\
1 \text { at bus 9 in } \\
\text { kvar }\end{array}$ & $\begin{array}{c}\text { STATCOM 2 } \\
\text { (Tracing mode) } \\
\text { at bus 10 in kvar }\end{array}$ & $\begin{array}{c}\text { STATCOM 3 } \\
\text { at bus 11 in } \\
\text { kvar }\end{array}$ & $\lambda_{\max }$ \\
\hline 1 & 0.01 & 0.01 & 2.5913 \\
\hline 1 & 0.5 & 0.01 & 2.5913 \\
\hline 1 & 1 & 0.01 & 2.5913 \\
\hline 1 & 1.5 & 0.01 & 2.5913 \\
\hline 1 & 2 & 0.01 & 2.5913 \\
\hline 1 & 3 & 0.01 & 2.5913 \\
\hline 1 & 4 & 0.01 & 2.5913 \\
\hline 1 & 5 & 0.01 & 2.5913 \\
\hline 1 & 6 & 0.01 & 2.5913 \\
\hline 1 & 7 & 0.01 & 2.5913 \\
\hline 1 & 8 & 0.01 & 2.5913 \\
\hline 1 & 9 & 0.01 & 2.5913 \\
\hline 1 & 10 & 0.01 & 2.5913 \\
\hline 1 & 12 & 0.01 & 2.5913 \\
\hline 1 & 13 & 0.01 & 2.5913 \\
\hline 1 & 14 & 0.01 & 2.5913 \\
\hline 1 & 15 & 0.01 & 2.5913 \\
\hline 1 & 17 & 0.01 & 2.5913 \\
\hline 1 & 19 & 0.01 & 2.5913 \\
\hline 1 & 20 & 0.01 & 2.5913 \\
\hline
\end{tabular}

Table 6: STATCOM 1 at bus 9 applied in tracing mode

\begin{tabular}{|c|c|c|c|}
\hline $\begin{array}{c}\text { STATCOM 1 } \\
\text { (Tracing mode) } \\
\text { at bus 9 in kvar }\end{array}$ & $\begin{array}{c}\text { STATCOM } \\
\text { at bus 10 in } \\
\text { kvar }\end{array}$ & $\begin{array}{c}\text { STATCOM } \\
\text { 3 at bus 11 } \\
\text { in kvar }\end{array}$ & $\lambda_{\max }$ \\
\hline 0.01 & 0.01 & 0.01 & 2.5913 \\
\hline 0.5 & 0.01 & 0.01 & 2.5913 \\
\hline 1 & 0.01 & 0.01 & 2.5913 \\
\hline 1.5 & 0.01 & 0.01 & 2.5913 \\
\hline 2 & 0.01 & 0.01 & 2.5913 \\
\hline 4 & 0.01 & 0.01 & 2.5913 \\
\hline 6 & 0.01 & 0.01 & 2.5913 \\
\hline 8 & 0.01 & 0.01 & 2.5913 \\
\hline 10 & 0.01 & 0.01 & 2.5913 \\
\hline 12 & 0.01 & 0.01 & 2.5913 \\
\hline 12.6 & 0.01 & 0.01 & 2.5913 \\
\hline
\end{tabular}




\begin{tabular}{|c|c|c|c|}
\hline 12.7 & 0.01 & 0.01 & 2.5953 \\
\hline 12.8 & 0.01 & 0.01 & 2.5953 \\
\hline 13 & 0.01 & 0.01 & 2.5953 \\
\hline 13.2 & 0.01 & 0.01 & 2.5953 \\
\hline 13.3 & 0.01 & 0.01 & 2.5944 \\
\hline 13.5 & 0.01 & 0.01 & 2.5918 \\
\hline 15 & 0.01 & 0.01 & 2.543 \\
\hline 18 & 0.01 & 0.01 & 2.3999 \\
\hline 20 & 0.01 & 0.01 & 2.3125 \\
\hline
\end{tabular}

The voltage magnitude profile and PV curves before and after placement of FACTS with contingency are shown in Figures 6-11. From Figures 6-11 it is clear that by using STATCOM and TCSC there is an improvement in voltage magnitude profile and maximum loading parameter using CSO for the contingency.

Like Line- 8 outage contingency, the optimal location and size of Line- 4 and Line-9 outages are obtained using Cat Swarm Optimization which are given in case 2 and case 3 as follows.

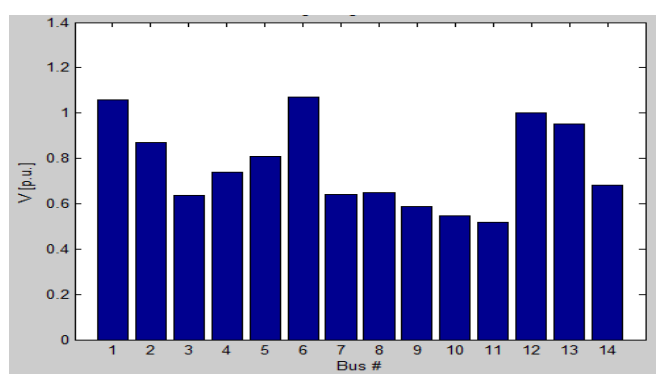

Fig 6. voltage magnitude profile before placement of FACTS

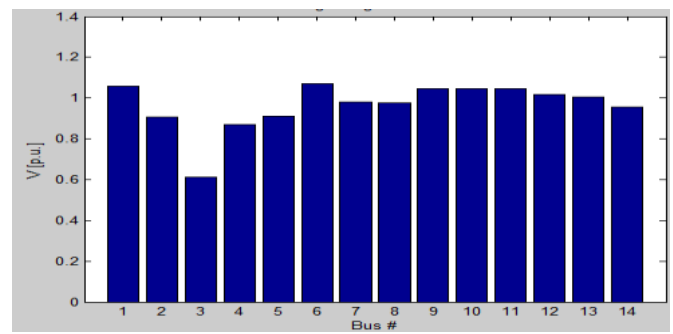

Fig 8. voltage magnitude profile after placement of TCSC

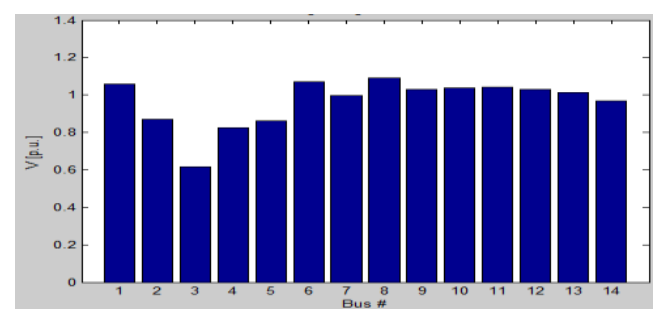

Fig 7. voltage magnitude profile after placement of STATCOM

\section{Case study 2}

\section{FACTS used (Line 4 outage)}

The best location and optimal size of TCSC devices for line 4 contingency is between buses 12-6, 13-12 and 14-13 with size is equal to $0.01 \mathrm{kvar}, 8.9 \mathrm{kvar}$ and $0.01 \mathrm{kvar}$.The best location and optimal size of STATCOM devices for line 4 contingency is at buses $12,131 \mathrm{nd} 14$ with size equal to $0.01 \mathrm{kvar}, 0.01 \mathrm{kvar}$ and $15.5 \mathrm{kvar}$. Whereas,

\section{Case study 3}

\section{FACTS used (Line 9 outage)}

The best location and optimal size of TCSC devices for line 9 contingency is between buses 12-6, 13-12 and 14-13 with size is equal to $0.01 \mathrm{kvar}, 0.01 \mathrm{kvar}$ and $12.1 \mathrm{kvar}$. The best location and optimal size of STATCOM devices for line 9 contingency is at buses $12,131 \mathrm{nd} 14$ with size equal to $0.01 \mathrm{kvar}, 0.01 \mathrm{kvar}$ and $0.01 \mathrm{kvar}$.

Table 8 shows that the improvement in voltage profile and maximum loading parameter before and after placement of FACTS for line 4, 8 and 9 contingencies. TCSC

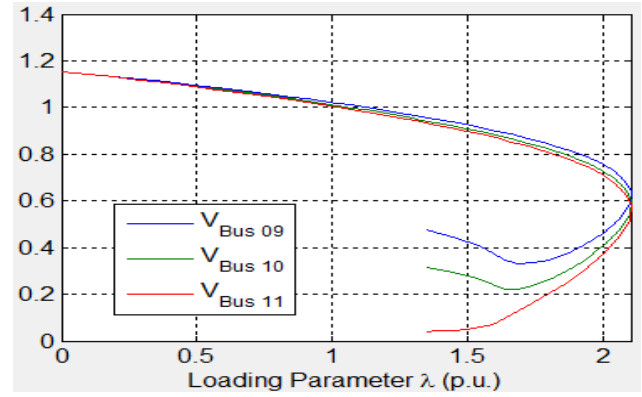

Fig 9. PV curves before placement of FACTS

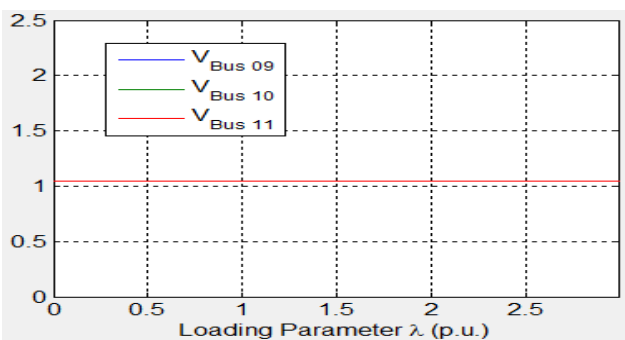

Fig 11. PV curves after placement of TCSC

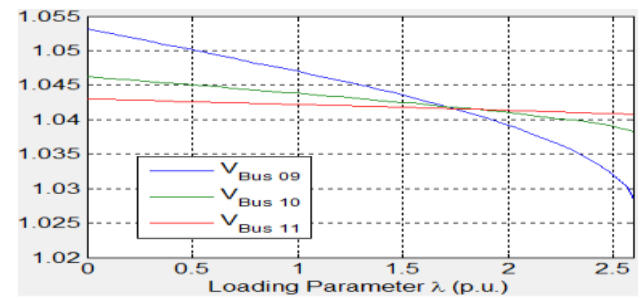

Fig 10. PV curves after placement of STATCOM

shows better performance in comparison to STATCOM as it gives better voltage profile and maximum loading ability. Although shunt controllers are used effectively for voltage control [15, 16], Series-connected controllers have to be designed to ride through contingency. TCSC is a primitive device, which is a series controller and very popular even today and it shows very good performance.

$F_{1}$ in the objective function is achieved. $F_{2}$ and $F_{3}$ which define the second and third part of the objective function is achieved from $\mathrm{F}_{1}$ as it is evident that the optimal placement of the FACTS controllers using CSO itself indicates the improvement of the steady state voltage stability limit in these test cases.

From the results it is clear that to state that the voltage magnitude profile, maximum loading parameter have been improved as compared with PSO [17]. 
Table 8 shows that the voltage magnitude profile for different buses. Out of this, voltage at bus-3 is seen not with in the stable limit. This can be considered a problem of voltage instability that can be overcome by decreasing the load at bus3. From Table 8 it is clear that using STATCOM there is no improvement in maximum loading parameter in

Line-4 outage. This can be considered as a problem but it can be addressed as a separate issue in future research work on this topic.

\section{CONCLUSION}

In this paper a novel approach is presented for voltage stability problem in wind power networks. The optimal location and the size of FACTS devices are identified before they are actually installed because the size of FACTS devices is high. Cat Swarm Optimization, a heuristic method to determine the optimal placement and VAR requirements of multiple TCSC's and STATCOM's to enhance the power system voltage stability under N-1 transmission line outage contingency is presented. The maximum loadability limit and voltage profile have been improved by placing the STATCOM and TCSC. In comparison to STATCOM, TCSC has given better results. CSO is observed to be more efficient in terms of convergence in comparison to PSO and other optimization algorithms.

\section{FUTURE SCOPE}

The future scope of this work includes the testing of this algorithm in practical power system and comparing it with other optimization algorithms.

\section{REFERENCES}

[1] Prabha Kundur, "Power System Stability and Control". Tata McGraw -Hill Education (INDIA); 1994.

[2] Taylor CW. "Power system voltage stability". New York: McGraw-Hill; 1994.

[3] Kothari DP, Nagarath IJ, "Modern power system analysis". Tata McGraw -Hill Education; 20003.

[4] Hingorani NG, Gyugyi L. "Understanding FACTS: concepts and technology of Flexible AC Transmission Systems". New York: IEEE Press; 20000.

[5] Dr.G.Naveen Kumar, M. Surya Kalavthi, K.Sasikala, G.Sruthi. "Optimal placement of multiple SSSC's with Cat Swarm Optimization under Line Outage Contingency". National Conference on HIGH VOLTAGE ENGINEERING, ISBN 978-81-928278-0-3.

[6] Bindeshwarsing, K.S. Verma, Deependrasingh, C.N. Singh, archnasingh, Ektaagrawal, Rahul dixit, Baljivtyagi. "Introduction to facts controllers a critical review". International Journal of Reviews in Computing $31^{\text {st }}$ December 2011. Vol.8, ISSN: 2076-3328, pages 194-234.

[7] Prabha Kundur (Canada, Convener), John Paserba (USA, Secretary), Venkat Ajjarapu (USA), Goran Andersson (Switzerland), Anjan Bose (USA), Claudio Canizares (Canada), Nikos Hatzargyriou (Greece), David Hill (Australia), Alex Stankovic (USA), Carson Taylor (USA), Thierry Van Custem (Belgium), and Vijay Vittal
(USA). "Definition and Classification of Power System Stability". IEEE transactions on power systems, vol-19, no.2, may 2004.

[8] Mostafa Alinezhad, Mehrdad Ahmadi Kamarposhti. "Static Voltage Stability Assesmant Considering the Power System Contingencies using Continuation Power Flow Method". International Journal of Electrical and Electronics Engineering 4:5 2010, pages 316-322.

[9] Dr.G.Naveen Kumar, M. Surya Kalavthi. "Cat Swarm Optimization for optimal placement of multiple UPFC's in voltage stability enhancement under contingency". Electrical Power and Energy Systems 57, 2014, pages 97-104.

[10] P.Suryakumari, Dr.P.Kantarao. "Power loss minimization using cat swarm optimization". IJAIEM, ISSN 2319-4847, Volume 2, Issue 9, September 2013 , pages 174-181.

[11] Meysam Orouskhani, Yasin Oruskhani, Mohammad Mansouri, Mohammad Teshnehlab. "A Novel Cat Swarm Optimization Algorithm for Unconstrained Optimization Problems". I.J. Information Technology and Computer science, 2013, 11, pages 32-41.

[12] Venu yarlagadda, Dr. B.V.Sankar Ram and Dr. K. R. M. Rao. "Automatic Control of Thyristor Controlled Series Capacitor (TCSC)". International Journal of Engineering Research and Applications (IJERA) ISSSN: 2248-9622, Vol.2, Issue 3, May-Jun 2012, pages 444-449.

[13] Shervin Samimian Tehrani, Peyman Salmanpour Bandaghiri. "Shunt Compensation for Improvement of Voltage Stability Using Static Synchronous Compensator (STATCOM) for Various Faults in Power System". IJAREEIE, Vol.3, Issue 6, June 2014, pages 9793-9800.

[14] G. Elsady, Y. A. Mobarak, and A.R Youssef. "STATCOM for Improved Dynamic Performance of Wind Farms in Power Grid". Proceedings of the $14^{\text {th }}$ International Middle East Power System Conference (MEPCON'10), Cairo University, Egypt, December 1921, 2010, Paper ID 207, pages 471-475.

[15] Chirag Tanti, Dinesh Pipalava. "Voltage Profile Improvement in Power System Using Series and Shunt Type FACTS Controller". International Journal of Science and Research (IJSR), ISSN (Online): 2319-7064, pages 2453-2456.

[16] Aswin R, Jo Joy. "Comparison between STATCOM and TCSC on Static Voltage Using MLP Index". International Journal of Advanced Research in Electrical, Electronics and Instrumentation Engineering. (An ISO 3297: 2007 Certified Organization), Vol.2, Special Issue 1, December 2013, pages 30-36.

[17] Abdelaziz Laifa, Mohamed Boudour. "Optimal Placement and Parameter Settings of Unified Power Flow Controller Device using a Perturbed Particle Swarm Optimization”. International Energy Conference, IEEE 2010, pages 205-210. 


\section{APPENDIX}

Table 7. N-1 contingency analysis for IEEE 14-bus system

\begin{tabular}{|c|c|c|c|c|c|c|c|c|c|c|c|c|c|c|c|c|}
\hline Bus & \multicolumn{16}{|c|}{ Voltage magnitude profile } \\
\hline & LO-1 & LO-2 & LO-3 & LO-4 & LO-5 & LO-6 & LO-7 & LO-8 & LO-9 & $\begin{array}{l}\text { LO- } \\
10\end{array}$ & $\begin{array}{l}\text { LO- } \\
11\end{array}$ & $\begin{array}{l}\text { LO- } \\
12\end{array}$ & $\begin{array}{l}\text { LO- } \\
13\end{array}$ & $\begin{array}{l}\text { LO- } \\
14\end{array}$ & $\begin{array}{l}\text { LO- } \\
15\end{array}$ & $\begin{array}{l}\text { LO- } \\
16\end{array}$ \\
\hline 1 & $\mathrm{AL}$ & $\mathrm{AL}$ & $\mathrm{AL}$ & $\mathrm{AL}$ & $\mathrm{AL}$ & AL & $\mathrm{AL}$ & $\mathrm{AL}$ & $\mathrm{AL}$ & $\mathrm{AL}$ & $\mathrm{AL}$ & $\mathrm{AL}$ & $\mathrm{AL}$ & $\mathrm{AL}$ & AL & $\mathrm{AL}$ \\
\hline 2 & $\mathrm{AL}$ & $\overline{\mathrm{AL}}$ & $\mathrm{AL}$ & $\mathrm{AL}$ & $\mathrm{AL}$ & $\overline{\mathrm{AL}}$ & $\mathrm{AL}$ & $\mathrm{AL}$ & $\mathrm{AL}$ & $\mathrm{AL}$ & $\overline{\mathrm{AL}}$ & $\mathrm{AL}$ & $\mathrm{AL}$ & $\mathrm{AL}$ & $\overline{\mathrm{AL}}$ & $\overline{\mathrm{AL}}$ \\
\hline 3 & $\begin{array}{l}0.546 \\
27\end{array}$ & $\mathrm{AL}$ & $\begin{array}{l}0.641 \\
46\end{array}$ & AL & $\mathrm{AL}$ & AL & $\begin{array}{l}0.647 \\
03\end{array}$ & $\mathrm{AL}$ & $\mathrm{AL}$ & $\begin{array}{l}0.570 \\
54\end{array}$ & $\mathrm{AL}$ & $\begin{array}{l}0.581 \\
24\end{array}$ & $\begin{array}{l}0.579 \\
39\end{array}$ & $\mathrm{AL}$ & $\mathrm{AL}$ & $\mathrm{AL}$ \\
\hline 4 & $\begin{array}{l}0.754 \\
49\end{array}$ & $\mathrm{AL}$ & $\begin{array}{l}0.842 \\
81\end{array}$ & $\mathrm{AL}$ & $\mathrm{AL}$ & $\mathrm{AL}$ & $\mathrm{AL}$ & $\mathrm{AL}$ & $\mathrm{AL}$ & $\mathrm{AL}$ & $\mathrm{AL}$ & $\begin{array}{l}0.786 \\
31\end{array}$ & $\mathrm{AL}$ & $\mathrm{AL}$ & $\mathrm{AL}$ & $\overline{\mathrm{AL}}$ \\
\hline 5 & $\begin{array}{l}0.789 \\
97\end{array}$ & $\mathrm{AL}$ & $\mathrm{AL}$ & $\mathrm{AL}$ & $\mathrm{AL}$ & $\mathrm{AL}$ & $\mathrm{AL}$ & $\mathrm{AL}$ & $\mathrm{AL}$ & $\mathrm{AL}$ & $\mathrm{AL}$ & $\begin{array}{l}0.831 \\
99\end{array}$ & $\mathrm{AL}$ & $\mathrm{AL}$ & $\mathrm{AL}$ & $\mathrm{AL}$ \\
\hline 6 & $\mathrm{AL}$ & $\mathrm{AL}$ & $\mathrm{AL}$ & $\mathrm{AL}$ & $\mathrm{AL}$ & AL & $\mathrm{AL}$ & $\mathrm{AL}$ & $\mathrm{AL}$ & $\mathrm{AL}$ & $\overline{\mathrm{AL}}$ & $\mathrm{AL}$ & $\mathrm{AL}$ & $\mathrm{AL}$ & $\overline{\mathrm{AL}}$ & $\overline{\mathrm{AL}}$ \\
\hline 7 & $\mathrm{AL}$ & $\mathrm{AL}$ & $\mathrm{AL}$ & $\mathrm{AL}$ & $\mathrm{AL}$ & $\begin{array}{l}0.780 \\
72\end{array}$ & $\mathrm{AL}$ & $\mathrm{AL}$ & $\mathrm{AL}$ & $\mathrm{AL}$ & $\mathrm{AL}$ & $\mathrm{AL}$ & $\begin{array}{l}0.733 \\
28\end{array}$ & $\mathrm{AL}$ & $\mathrm{AL}$ & $\mathrm{AL}$ \\
\hline 8 & $\mathrm{AL}$ & $\mathrm{AL}$ & $\mathrm{AL}$ & $\mathrm{AL}$ & $\begin{array}{l}0.796 \\
17\end{array}$ & $\begin{array}{l}0.750 \\
17\end{array}$ & $\mathrm{AL}$ & $\mathrm{AL}$ & $\mathrm{AL}$ & $\mathrm{AL}$ & $\mathrm{AL}$ & $\mathrm{AL}$ & $\mathrm{AL}$ & $\mathrm{AL}$ & $\mathrm{AL}$ & $\overline{\mathrm{AL}}$ \\
\hline 9 & AL & AL & $\mathrm{AL}$ & AL & $\begin{array}{l}0.799 \\
28\end{array}$ & $\begin{array}{l}0.772 \\
16\end{array}$ & $\mathrm{AL}$ & $\begin{array}{l}0.586 \\
68\end{array}$ & AL & AL & $\begin{array}{l}0.667 \\
84\end{array}$ & $\mathrm{AL}$ & $\begin{array}{l}0.761 \\
21\end{array}$ & $\begin{array}{l}0.874 \\
49\end{array}$ & $\begin{array}{l}0.92 \\
31\end{array}$ & $\begin{array}{l}0.662 \\
94\end{array}$ \\
\hline 10 & $\mathrm{AL}$ & $\mathrm{AL}$ & $\mathrm{AL}$ & $\mathrm{AL}$ & $\mathrm{AL}$ & $\mathrm{AL}$ & $\mathrm{AL}$ & $\begin{array}{l}0.544 \\
88\end{array}$ & $\mathrm{AL}$ & $\mathrm{AL}$ & $\begin{array}{l}0.703 \\
6\end{array}$ & $\mathrm{AL}$ & $\begin{array}{l}0.761 \\
21\end{array}$ & $\begin{array}{l}0.848 \\
4\end{array}$ & $\begin{array}{l}0.92 \\
488\end{array}$ & $\begin{array}{l}0.654 \\
36\end{array}$ \\
\hline 11 & $\mathrm{AL}$ & $\mathrm{AL}$ & $\mathrm{AL}$ & $\mathrm{AL}$ & $\mathrm{AL}$ & AL & $\mathrm{AL}$ & $\begin{array}{l}0.518 \\
85\end{array}$ & $\mathrm{AL}$ & $\mathrm{AL}$ & $\overline{\mathrm{AL}}$ & $\mathrm{AL}$ & $\begin{array}{l}0.902 \\
59\end{array}$ & $\mathrm{AL}$ & $\overline{\mathrm{AL}}$ & $\overline{\mathrm{AL}}$ \\
\hline 12 & $\mathrm{AL}$ & $\begin{array}{l}0.656 \\
54\end{array}$ & $\mathrm{AL}$ & $\begin{array}{l}0.594 \\
33\end{array}$ & $\mathrm{AL}$ & $\overline{A L}$ & $\mathrm{AL}$ & $\mathrm{AL}$ & $\begin{array}{l}0.573 \\
45\end{array}$ & $\mathrm{AL}$ & $\overline{\mathrm{AL}}$ & $\mathrm{AL}$ & $\begin{array}{l}1.021 \\
8\end{array}$ & $\mathrm{AL}$ & $\mathrm{AL}$ & $\overline{\mathrm{AL}}$ \\
\hline 13 & $\mathrm{AL}$ & $\begin{array}{l}0.650 \\
23\end{array}$ & $\mathrm{AL}$ & $\begin{array}{l}0.581 \\
42\end{array}$ & $\mathrm{AL}$ & $\mathrm{AL}$ & $\begin{array}{l}0.700 \\
29\end{array}$ & $\mathrm{AL}$ & $\begin{array}{l}0.618 \\
75\end{array}$ & $\begin{array}{l}0.737 \\
34\end{array}$ & $\mathrm{AL}$ & $\mathrm{AL}$ & $\begin{array}{l}0.994 \\
09\end{array}$ & $\mathrm{AL}$ & $\mathrm{AL}$ & $\mathrm{AL}$ \\
\hline 14 & $\overline{\mathrm{AL}}$ & $\begin{array}{l}0.649 \\
58\end{array}$ & $\begin{array}{l}0.846 \\
63\end{array}$ & $\begin{array}{l}0.572 \\
28\end{array}$ & $\begin{array}{l}0.808 \\
63\end{array}$ & $\overline{\mathrm{AL}}$ & $\begin{array}{l}0.667 \\
7\end{array}$ & $\overline{\mathrm{AL}}$ & $\begin{array}{l}0.582 \\
54\end{array}$ & $\begin{array}{l}0.714 \\
12\end{array}$ & $\begin{array}{l}0.711 \\
29\end{array}$ & $\mathrm{AL}$ & $\begin{array}{l}0.875 \\
58\end{array}$ & $\begin{array}{l}0.858 \\
85\end{array}$ & $\begin{array}{l}0.88 \\
903\end{array}$ & $\begin{array}{l}0.529 \\
25\end{array}$ \\
\hline $\begin{array}{l}\text { ML } \\
P\end{array}$ & $\begin{array}{l}2.412 \\
6\end{array}$ & $\begin{array}{l}1.707 \\
4\end{array}$ & $\begin{array}{l}1.386 \\
9\end{array}$ & $\begin{array}{l}2.434 \\
3\end{array}$ & $\begin{array}{l}2.802 \\
3\end{array}$ & $\mathrm{AL}$ & $\begin{array}{l}1.922 \\
8\end{array}$ & $\begin{array}{l}2.104 \\
1\end{array}$ & $\begin{array}{l}1.543 \\
4\end{array}$ & 2.507 & $\begin{array}{l}2.779 \\
6\end{array}$ & 2.546 & $\begin{array}{l}2.294 \\
1\end{array}$ & $\begin{array}{l}2.827 \\
5\end{array}$ & $\begin{array}{l}2.83 \\
04\end{array}$ & $\begin{array}{l}1.980 \\
2\end{array}$ \\
\hline
\end{tabular}

LO: Line Outage; AL: Acceptable Limit

Table 8: Voltage profile before and after contingency

\begin{tabular}{|c|c|c|c|c|c|c|c|c|c|c|}
\hline $\begin{aligned} \text { Bus } & \\
& n \\
& 0\end{aligned}$ & $\begin{array}{l}\text { V (p.u.) } \\
\text { before } \\
\text { Contin } \\
\text { gency } \\
\text { (with-out } \\
\text { FACT } \\
\text { S) }\end{array}$ & $\begin{array}{l}\text { V (p.u.) } \\
\text { after } \\
\text { Contin } \\
\text { gency } \\
\text { (line 4) }\end{array}$ & $\begin{array}{l}\text { V (p.u.) after } \\
\text { Contin } \\
\text { gency (line 4) } \\
\text { (with } 3 \\
\text { TCSC's) }\end{array}$ & $\begin{array}{l}\text { V (p.u.) after } \\
\text { Contin } \\
\text { gency (line } \\
\text { 4) } \\
\text { (with } 3 \\
\text { STAT } \\
\text { COM') }\end{array}$ & $\begin{array}{l}\text { V (p.u.) } \\
\text { after } \\
\text { Contin } \\
\text { gency } \\
\text { (line 8) }\end{array}$ & $\begin{array}{l}\text { V (p.u.) } \\
\text { after } \\
\text { Contin } \\
\text { gency } \\
\text { (line } \\
\text { 8)(w } \\
\text { ith } 3 \\
\text { TCS } \\
\text { C's) }\end{array}$ & $\begin{array}{l}\text { V (p.u.) after } \\
\text { Contin } \\
\text { gency (line } \\
\text { 8)(with } \\
3 \\
\text { STAT } \\
\text { COM') }\end{array}$ & $\begin{array}{l}\text { V (p.u.) } \\
\text { after } \\
\text { Contin } \\
\text { gency } \\
\text { (line 9) }\end{array}$ & $\begin{array}{l}\text { V (p.u.) } \\
\text { after } \\
\text { Contin } \\
\text { gency } \\
\text { (line 9) } \\
\text { (with } 3 \\
\text { TCS } \\
\text { C's) }\end{array}$ & $\begin{array}{l}\text { V (p.u.) after } \\
\text { Contin } \\
\text { gency (line } \\
\text { 9) } \\
\text { (with3 } \\
\text { STAT } \\
\text { COM') }\end{array}$ \\
\hline 1 & 1.0575 & 1.058 & 1.0588 & 1.0569 & 1.0571 & 1.058 & 1.0569 & 1.0575 & 1.058 & 1.0568 \\
\hline 2 & 0.94713 & 0.96193 & 0.97791 & 0.87484 & 0.87141 & 0.906 & 0.87127 & 0.90111 & 0.90488 & 0.86397 \\
\hline 3 & 1.01 & 1.01 & 1.01 & 0.61762 & 0.63694 & 0.61117 & 0.61667 & 0.73728 & 0.61843 & 0.59828 \\
\hline 4 & 0.87394 & 0.81668 & 0.92979 & 0.75529 & 0.73742 & 0.87168 & 0.8237 & 0.75618 & 0.85292 & 0.80313 \\
\hline 5 & 0.89297 & 0.81431 & 0.94633 & 0.80368 & 0.80883 & 0.90969 & 0.86012 & 0.78554 & 0.90395 & 0.84361 \\
\hline 6 & 1.07 & 0.65435 & 0.9675 & 1.07 & 1.07 & 1.07 & 1.07 & 0.69408 & 1.07 & 1.07 \\
\hline 7 & 0.80459 & 0.84377 & 0.94209 & 0.83464 & 0.63971 & 0.97905 & 0.99598 & 0.6934 & 0.93231 & 0.94338 \\
\hline 8 & 0.76841 & 1.09 & 1.09 & 0.85754 & 0.64989 & 0.97968 & 1.09 & 0.71874 & 1.09 & 1.09 \\
\hline
\end{tabular}


International Journal of Computer Applications (0975 - 8887)

Volume 125 - No.11, September 2015

\begin{tabular}{|l|l|l|l|l|l|l|l|l|l|l|}
\hline 9 & 0.79139 & 0.7133 & 0.84996 & 0.85744 & 0.58668 & 1.045 & 1.0285 & 0.6449 & 0.87444 & 0.92576 \\
\hline 10 & 0.81295 & 0.6747 & 0.82993 & 0.874 & 0.54488 & 1.045 & 1.0382 & 0.63448 & 0.87965 & 0.92937 \\
\hline 11 & 0.92704 & 0.65125 & 0.87259 & 0.96017 & 0.51885 & 1.045 & 1.0407 & 0.65496 & 0.95754 & 0.98831 \\
\hline 12 & 1.0058 & 0.59433 & 1.045 & 1.0405 & 1.0011 & 1.0174 & 1.0292 & 0.57345 & 1.045 & 1.0354 \\
\hline 13 & 0.971 & 0.58142 & 1.045 & 1.0383 & 0.94992 & 1.0069 & 1.0126 & 0.61875 & 1.045 & 1.0421 \\
\hline 14 & 0.80136 & 0.57228 & 1.045 & 1.0275 & 0.6821 & 0.9539 & 0.96937 & 0.58254 & 1.045 & 1.0316 \\
\hline $\begin{array}{l}\text { MLP } \\
\left(\lambda_{\max }\right)\end{array}$ & 2.8453 & 2.4343 & 3.4596 & 2.2107 & 2.1041 & 2.989 & 2.5953 & 1.5434 & 2.8952 & 2.5474 \\
\hline
\end{tabular}

